Available online at GSC Online Press Directory

GSC Biological and Pharmaceutical Sciences

e-ISSN: 2581-3250, CODEN (USA): GBPSC2

Journal homepage: https://www.gsconlinepress.com/journals/gscbps

(RESEARCH ARTICLE)

\title{
Microbiological assessment of biofilm formation on different water storage containers
}

\author{
Ezenobi Nkechi Obiofu *, Ogbu Hanson Ige and Eneogwe Noble Chikezie \\ Department of Pharmaceutical Microbiology and Biotechnology, Faculty of Pharmaceutical Sciences, University of Port \\ Harcourt, Choba P.M.B.5323, Port Harcourt, Rivers State, Nigeria.
}

Publication history: Received on 29 November 2018; revised on 13 December 2018; accepted on 21 December 2018

Article DOI: https://doi.org/10.30574/gscbps.2018.5.3.0150

\begin{abstract}
Providing safe drinking-water, especially to those in developing countries, is still a major problem. These problems are divers and serious. Worst still, is the issue of scarcity, which has encouraged water storage in containers for future use. Long period of storage may lead to the formation of biofilms. This study aims to monitor the formation of biofilms in different water storage containers, using viable and total coliform counts as indicators, carry out isolation and characterization of organism that may possibly be responsible for the biofilm formation. Water storage containers used include polyethylene, plastic, glass, rubber, galvanized steel, aluminium, stainless steel and clay. Weekly sampling and analysis were performed by measuring $\mathrm{pH}$, viable and total coliform counts using plate count and Most Probable Number technique while the biofilm formed in each container was weighed. The results showed that polyethylene had the highest degree of biofilm formation weighing $0.090 \mathrm{~g}$ while galvanized and stainless steel had the lowest level of biofilm formation weighing $0.010 \mathrm{~g}$. Statistically, there was a difference between polyethylene and galvanized steel and aluminium and stainless steel as their p-values were less than 0.05 . There was no statistical difference between glass and plastic and between plastic and rubber. Pseudomonas aeruginosa was identified as the biofilm forming organism in the different water storage containers. The findings strengthen evidence that pathogenic bacteria entering or already present in water storage systems can survive in biofilms for at least several weeks, even under unfavourable conditions, and may be a risk to consumers of such water.
\end{abstract}

Keywords: Biofilm; microbial cells; stored water; storage containers; viable counts; Pseudomonas aeruginosa

\section{Introduction}

Water is a limited natural resource and is becoming increasingly important to human health, food security and the environment [1, 2]. It's at the core of sustainable development and is critical for socio-economic development, energy and food production, healthy ecosystems and for human survival itself [1-4]. As the global population grows, there is an increasing need to balance all the competing demands on water resources so that everyone has enough for their needs. The conflicts over water are often precipitated by a failure to meet demands for household, agriculture and industrial uses as well as for environmental and /or ecosystem service $[1,3,5]$. In developing countries, the issues of water supply are divers and serious [6]. The problem of natural scarcity of portable water supply has encouraged water storage in containers for future use. Water storage is mainly achieved by collecting surface, ground water or rain water harvesting $[7,8]$. Water contained within water storage containers can be contaminated through poor handling, unclean containers, unhygienic domestic water handling practices, and natural contamination from the ambient domestic environment into containers [8]. If any of these occur, introduced contaminants may interact with the surfaces of the containers and become entrained in biofilms. Previous reports have shown that biofilms may form on a wide variety of living and non-living surfaces, and can be prevalent in natural, industrial and hospital settings [9-11].

\footnotetext{
${ }^{*}$ Corresponding author

E-mail address: nkechi.ezenobi@uniport.edu.ng
}

Copyright (C) 2018 Author(s) retain the copyright of this article. This article is published under the terms of the Creative Commons Attribution Liscense 4.0. 
The ability of microorganisms to attach to diverse surfaces and form complex colonies known as biofilms vastly improves their survival and growth in environmental niches [12]. This strategy represents a protected mode of growth that not only allows cells to survive in hostile environments, but also to colonize new niches by dispersal of microorganisms from the microbial clusters [9, 10,12]. Every microbial biofilm community is reported to be very unique, even though some structural attributes can generally be considered universal $[9,13]$. The manner in which they are also formed are essentially the same in whatever ecosystem they inhabit [9]. As defined by Donlan [14], a biofilm is an assemblage of microbial cells that is irreversibly associated with a surface and enclosed within a self-produced extracellular matrix [15] made up of polysaccharide material $[9,14,16]$. The polysaccharide materials is slime like, very adhesive and functions as a coating to encourage the attachment of other organism in order to trap nutrients and provide a degree of protection as previously mentioned [9]. The microbial cells exhibit an altered phenotype with respect to growth rate and gene transcription [9,14] including changes in metabolic activity [17, 18] which confers resistance to antimicrobial therapy and host mechanisms of clearance [19-21]. Other processes involved are product formation, detachment, erosion or sloughing of biofilm from the surface [22]. Organisms composing the biofilm may also have a marked effect on the biofilm structure, which Arampatzi et al. [9], James et al. [23] have attributed to the ability of one specie to enhance the stability of the other. Although structure may also be influenced by the interaction of particles of non microbial components from the host or environment [9].

As earlier mentioned, the conditions under which the water is stored often affects the quality of the water [8]. Previous studies by Jagals et al. [24], van der Merwe et al. [8] indicates that stored water is more susceptible to environmental influences and contamination than if the water were still in its natural habitat. Several authors including Jagals et al. [24], Momba and Kaleni [25], Momba and Notshe [7], van der Merwe et al. [8] have reported on the microbial quality of water stored in small household containers and the results of their findings showing high levels of objectionable organisms that are unsafe for human consumption. Similar studies by Momba and Kaleni [25], Momba and Notshe [7] have also shown that water stored in plastic based materials, are able to support more bacterial incorporation into biofilms on their interior surfaces than those made of metal based materials. Their studies also revealed that plastic based containers have a greater affinity to support the incorporation of faecal coliforms into biofilm structures. van der Merwe et al. [8] reported that these biofilms can act as reservoirs for pathogenic microorganisms, that can, through growth and detachment, be responsible for most of the planktonic cells found in the aqueous environment. This is of great concern as storage of untreated water supplies which may be contaminated with pathogens such as $P$. aeruginosa, S. epidermidis, E. coli, S. aureus, E. cloacae, K. pneumoniae can provide an ideal environment for microbial proliferation and biofilm formation $[11,21,26]$. This study was designed to monitor the development and quantify biofilms formation in different water storage containers, using viable and total coliform counts as indicators. A second objective was to isolate and characterize organism that may possibly be responsible for the biofilm formation.

\section{Materials and methods}

\subsection{Sample collection and storage}

The water sample was collected from the tap (groundwater, pumped to the overhead tank) located near the Pharmaceutical Microbiology laboratory, University of Port Harcourt, Rivers State. The water samples were collected in a sterilized polyethylene, plastic, glass, rubber (polyvinyl chloride), galvanized steel, aluminium, stainless steel and clay containers. A treated water in a polyethylene container served as control. The samples were labeled and transported immediately to pharmaceutical microbiology laboratory, University of Port Harcourt for examination and storage.

\section{2. pH determination}

The $\mathrm{pH}$ of the different water samples was determined on the first day and after eight weeks of storage using the method described by Okpo et al. [5] with some modification. The pH meter (pHS 25) was standardized with buffer solution of pH 4, 7 and 9.14 and to avoid cross contamination of the samples, the electrode tip was rinsed with the water to be tested, before taking measurements. $\mathrm{pH}$ meter reading was taken, when the display becomes stable and the results of each measurement recorded accordingly.

\subsection{Most probable number counts}

The water samples were analyzed for the presence of coliforms using the Most Probable Number (MPN) technique previously described by $[27,28]$. The three tubes MPN method was followed for the analysis of coliforms in the water on day one and after eight weeks of storage. The presence of acid is indicated by color change of the medium and the presence of gas is detected as gas bubbles collected in the inverted Durham tube present in the medium. The number of total coliforms is determined by counting the number of tubes giving positive reaction (colour change and gas production) and comparing the pattern of positive results (the number of tubes showing growth at each dilution) with 
standard statistical tables. If the presumptive test is negative, no further testing is performed, and the water source is considered microbiologically safe. If, however, any tube in the series shows acid and gas, the water is considered unsafe and the confirmed test is performed on the tube displaying a positive reaction.

\subsection{Enumeration of viable cell}

Viable aerobic count was performed on all samples using spread plate technique on Plate count agar (Lab M, UK) and Sabouraud dextrose agar (Lab M, UK) as previously described [29-31]. The PCA plates were incubated at $37{ }^{\circ} \mathrm{C}$ for 24 hours while SDA plates at $25^{\circ} \mathrm{C}$ for 5 days. Uninoculated plates containing only the sterile media were used as blank to compare the different samples. After the incubation period, discrete colonies were counted using a colony counter and the total aerobic counts expressed as $\mathrm{CFU} / \mathrm{mL}$.

\subsection{Isolation and identification of microbial isolates}

Tests for the isolation of possible microbial contaminants were conducted after eight weeks of storage on all sample containers. A sterile swab sticks was used to swab the inner walls of each container, and the swab from each container was thereafter streaked on the surfaces of Mannitol salt agar (HIMEDIA, India), Salmonella shigella agar (Lab M, UK),, MacConkey agar (Lab M, UK), and cetrimide nutrient agar in duplicate. After overnight incubation at $37^{\circ} \mathrm{C}$, colonies were identified and characterized using colony characteristics, gram reaction of the organisms and biochemical test following standard procedure [32,33].

\subsection{Biofilm quantification}

Quantification was performed by taking the weight of the empty containers before the start of experiment and after 8 weeks of storage. The difference between initial and final weight was recorded as weight of the biofilm formed.

\subsection{Statistical analysis}

Statistical analysis using one-way analysis of variance method to compare the results obtained in all the containers was performed. A p-value of less than or equal to 0.05 is considered to be statistically significant [34].

\section{Results}

\section{1. pH determination}

The results of $\mathrm{pH}$ measurement are presented in Figure 1. The $\mathrm{pH}$ of the control sample increased from 6.88 at the start to 8.22 on the eight weeks of the study. pH level of the water samples in all eight container types was 5.79 at the start of experiment and on the final week, it had changed to $6.34,6.37,6.81,6.88,7.21,7.86,8.02$, 8.20 respectively for polyethylene, clay, glass, plastic, plastic, rubber, stainless steel, aluminum, galvanized steel containers.

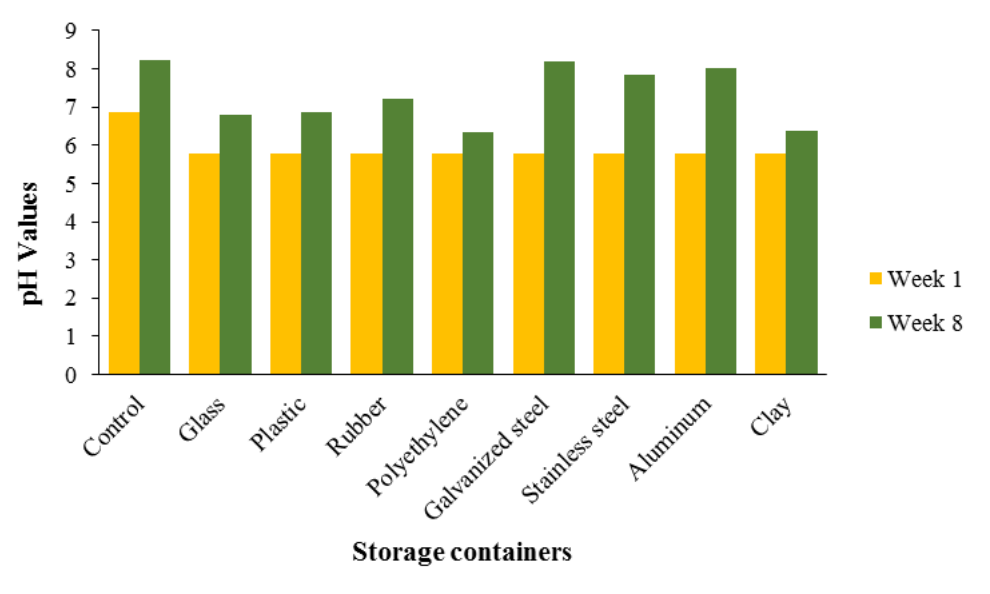

Figure $1 \mathrm{pH}$ levels of water stored in different waters containers during week 1 and 8 of the study

\subsection{Most probable number}

Results of the statistical value of Most Probable Number (MPN) per $100 \mathrm{~mL}$ of water for both the control and water samples at week 1 and week 8 of the study using three tubes of different dilution is presented in Tables 1 . 
Table 1 Most probable number per $100 \mathrm{~mL}$ of water for each container before and after week 8 of storage using three tubes of each dilution

\begin{tabular}{|c|c|c|c|c|c|c|c|c|}
\hline \multirow{2}{*}{$\begin{array}{l}\text { Storage } \\
\text { container }\end{array}$} & \multicolumn{3}{|c|}{ Week 1} & \multirow{2}{*}{$\begin{array}{c}\text { MPN/ } \\
100 \mathrm{~mL}\end{array}$} & \multicolumn{3}{|c|}{ Week 8} & \multirow{2}{*}{$\begin{array}{c}\text { MPN/ } \\
100 \mathrm{~mL}\end{array}$} \\
\hline & $10 \mathrm{~mL}$ & $1 \mathrm{~mL}$ & $0.1 \mathrm{~mL}$ & & $10 \mathrm{~mL}$ & $1 \mathrm{~mL}$ & $0.1 \mathrm{~mL}$ & \\
\hline Control & --- & +-- & --- & 3 & --- & +-- & --- & 3 \\
\hline Glass & +++ & ++- & ++- & 210 & ++- & ++- & +++ & 42 \\
\hline Plastic & +++ & ++- & ++- & 210 & ++- & ++- & +-- & 28 \\
\hline Rubber & +++ & ++- & ++- & 210 & ++- & ++- & +-- & 28 \\
\hline Polyethylene & +++ & ++- & ++- & 210 & +++ & ++- & +++ & 290 \\
\hline Galvanized steel & +++ & ++- & ++- & 210 & +-- & +-- & --- & 7.3 \\
\hline Stainless steel & +++ & ++- & ++- & 210 & ++- & +-- & +-- & 20 \\
\hline Aluminum & +++ & ++- & ++- & 210 & +-- & +++ & ++- & 24 \\
\hline Clay & +++ & ++- & ++- & 210 & ++- & +++ & +++ & 53 \\
\hline
\end{tabular}

\subsection{Microbial enumeration}

Microbial enumeration tests are required to demonstrate the quality of water under acceptable hygienic conditions and data obtained from the first week up to the eight weeks are presented in Figure 2. The samples analysed were uncontaminated with fungi as shown from the Sabouraud dextrose agar (SDA) plates. This is obviously due to the absence of planktonic fungi in the water tested. However, there was the presence of viable and potentially pathogenic microorganisms, Pseudomonas aeruginosa in all the water samples tested with exception of the control.

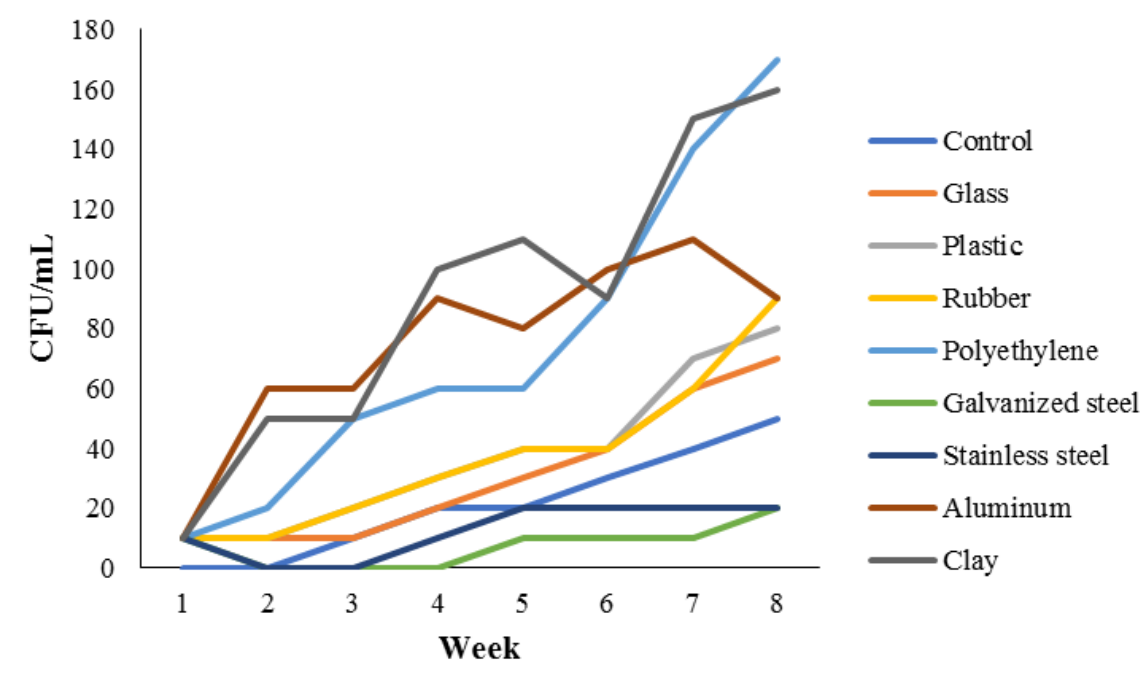

Figure 2 Graph showing total viable cell count of water stored in different containers from week 1 to 8

\subsection{Biofilm determination}

Figure 3 shows the weight of biofilm formed in each of the water storage container, which was determined by difference between the final weight of the container after the water was discarded on the eight weeks of storage and the initial weight of the empty container before the experiment commenced. The result of biofilm formed after the end of the study showed that water stored in control container (treated water), glass, plastic and rubber (PVC), polyethylene had the weights as $0.002 \mathrm{~g}, 0.04 \mathrm{~g}, 0.03 \mathrm{~g}$ and $0.05 \mathrm{~g}, 0.09 \mathrm{~g}$ respectively, while biofilm formed in galvanized steel, stainless steel aluminum and clay containers had the weights of $0.01 \mathrm{~g}, 0.010 \mathrm{~g}, 0.050 \mathrm{~g}$ and $0.070 \mathrm{~g}$ respectively. 


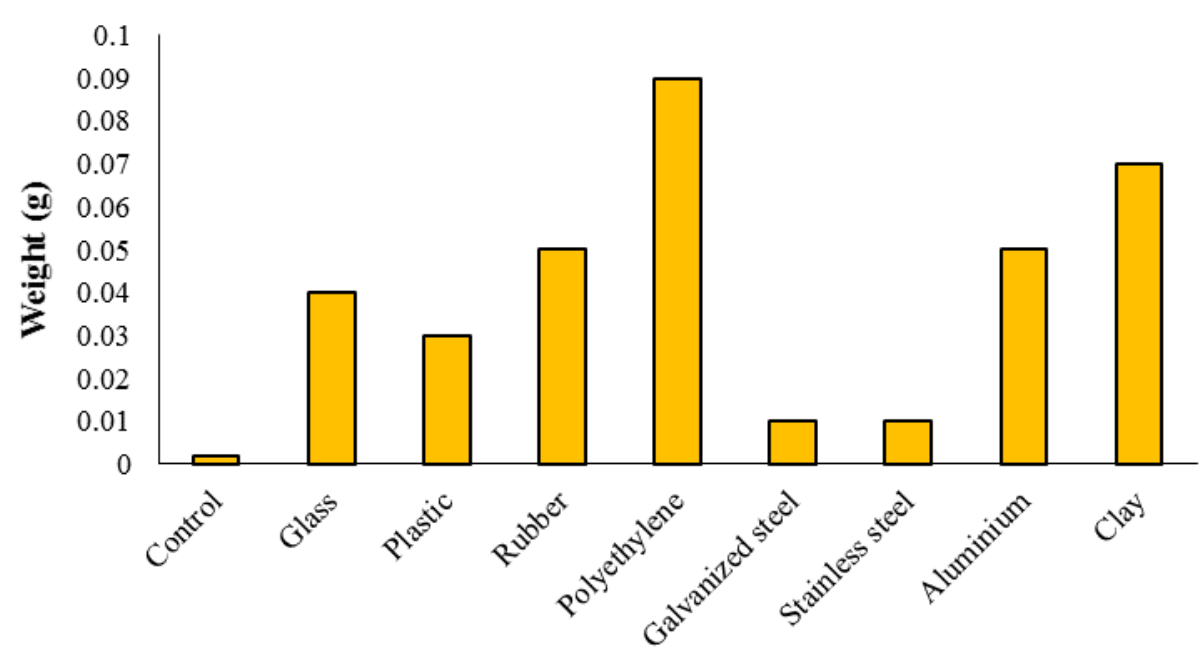

Storage containers

Figure 3 Graph showing weight of biofilms forms in different containers after 8 weeks of storage

\section{Discussion}

Biofilm formation begins when free-floating microorganisms such as bacteria come in contact with an appropriate surface and follows through a series of events leading to adaptation under diverse nutritional and environmental conditions $[12,35]$. In this study we aimed at monitoring the development and formation of biofilms in different water storage containers, using total aerobic counts as indicators as well as isolating and characterizing the presence of any contaminant organism. The water sample examined was collected from the tap (groundwater, pumped to the overhead tank) and distributed in equal amount onto sterilized polyethylene, plastic, glass, rubber (polyvinyl chloride), galvanized steel, aluminum, stainless steel and clay containers using treated water in a polyethylene container as control.

The present study has demonstrated that microorganisms are widespread in nature and that the type of container used to store water could impacts the $\mathrm{pH}$ of the water stored in them. Water stored in galvanized and stainless steel recorded the highest $\mathrm{pH}$ value, while the least value was recorded for water stored in polyethylene container. As shown in figure $1, \mathrm{pH}$ of all the polymer containers was close to the neutral $\mathrm{pH}$ which is within the optimal range that support growth of most microorganisms, and similar to an earlier report by Baird [36]. The presence of $P$. aeruginosa indicates a possible contamination prior to storage. This might have come directly from the water sources or from dust deposits or during the process of handling. Organisms naturally occurring within water systems strive to form a biofilm as the ideal condition for surviving and reproducing. According to Jamal et al. [35] increased attachment will occur due to increase critical level in flow velocity, temperature of water or nutrients concentrations. The nutrient levels need only be relatively low such as 2,000 microgram per liter on a standard agar plate, 0.5 microgram per liter in a purified water system to allow a community to flourish $[37,38]$. For P. aeruginosa the presence of locomotor structures on cell surfaces such as flagella, pili, fimbriae, proteins or polysaccharides may have provided an advantage amongst other organisms [35].

The MPN result presented in Table 1 suggests that polyethylene container harboured the highest number of bacteria than other containers and would probably support the larger biofilm formation. Earlier studies have shown that biofilms in drinking water systems can serve as reservoirs for several organisms such as Helicobacter pylori, Legionellae species, Mycobacterium avium and free-living protozoa increasingly recognized for harbouring pathogens [38-41].

Water stored in all the polymer containers, glass, aluminum and clay showed growth except galvanized steel and stainless steel. Growth was highest in aluminum and clay recording 60 and 50 colony forming unit per millilitre (CFU/mL) respectively, affirming earlier report by Rajagopal et al. [42] that clay material have the ability to support microbial growth. The result of total viable cell count for week three, showed an increase in bacterial count from 20 to $50 \mathrm{CFU} / \mathrm{mL}$ for water stored in polyethylene, while glass, plastic and rubber showed a minimum growth of 10 to 20 $\mathrm{CFU} / \mathrm{m}$. Result from week 4, 5, 6, 7 and 8 showed an increase in total viable count of all the materials at 1/100 dilution, but water stored in polyethylene, aluminium and clay showed higher growth similar to findings by Maggy and Kaleni [25]. The growth recorded in water stored in polymer containers like plastic, rubber (PVC), polyethylene and that of 
glass containers could be attributed to the leaching of materials used in their production which may have served as nutrient for the organisms as previously reported [43]. It was observed that water stored in galvanized and stainless steel showed limited growth at $1 / 100$ dilution during the $4^{\text {th }}$ and $3^{\text {rd }}$ week respectively. Water stored in aluminium showed growth throughout the 8 weeks with the peak growth of $110 \mathrm{CFU} / \mathrm{mL}$ at week 7 of the study. According to Tang and Cooney [44] the added paint materials present in galvanized and stainless containers may have contributed to the to the decrease in the number of colonies forming unit recorded in this study as opposed to the aluminium container. Statistically, CFU/mL obtained from water of control and glass containers showed no comparable difference as their $\mathrm{p}$ value was more than 0.05 . For the plastic, rubber, aluminium and clay there was no comparable difference between them as their $\mathrm{p}$ value was greater than 0.05 (statistically insignificant). There was a significant difference in comparison between polyethylene, galvanized steel, stainless steel and aluminium as their $\mathrm{p}$ values were less than 0.050 .

In this study, the degree at which biofilm formed varied from one container to another. This could be due to the nature, chemical and physical composition of the various container used in the study as earlier reported [45]. As shown in Figure 3, biofilm formed in polyethylene container was higher than the rest of the containers. This may be due to the hydrophobic nature of the surfaces of these polymers which seems to boost adhesion of cells that consequently leads to biofilm formation as previously [46]. Higher biofilm formation may also be as a result of leaching of the materials used in the manufacture of the containers and hence serve as nutrient for the growth of bacterial cell [47]. The galvanized and stainless-steel containers recorded the least level of biofilm formation, which may also be due to the hydrophilic nature of the surfaces and therefore requiring a longer exposure time to increase the chances of any microbial attachment [25]

\section{Conclusions}

The results from the current study confirmed that long term storage can influence water quality and increase the number of viable cells on water storage containers. Pseudomonas aeruginosa was identified as the biofilm forming organism in the different water storage containers while the most suitable containers for storing drinking water are galvanized steel or stainless steel. Aluminium, clay, glass and polymer containers are not recommended for long term storage of water as they have the potential to support biofilm formation, which may be detrimental to public health. Since water stored in container in domestic environment are far more subject to environmental influences such as contamination by nutrient than water in closed pipe distribution system, it is reasonable to assume that biofilm-like substances could also build up in containers. Therefore, untreated water should not be stored for a long period of time since cells growing within a biofilm have spatial and temporal responses to their immediate environment for nutrient, oxygen availability and interactions with metabolic waste. This unique physiologic state can allow for tolerance and development of persistent and/or dormant cells and may be a risk to consumers of such water.

\section{Compliance with ethical standards}

\section{Acknowledgments}

The authors wish to thank the Department of Pharmaceutical Microbiology \& Biotechnology, Faculty of Pharmaceutical Sciences, University of Port Harcourt, Nigeria for the permission to use some of her facilities for this research work.

\section{Disclosure of conflict of interest}

The authors declare that the research was conducted in the absence of any commercial or financial relationships that could be construed as a potential conflict of interest.

\section{References}

[1] WHO/UNICEF. (2000). Global Water Supply and Sanitation Assessment. In: World Health Organization and United Nations Children's Fund Joint Monitoring Program for Water Supply and Sanitation. New York.

[2] Mir AH, Jehangir A, Bhat SU and Jan L. (2013). Evaluation of Drinking Water, Sanitation and Hygiene Conditions at the World Famous Tourist Station Pahalgam, Kashmir, India. International Journal of Environment and Bioenergy, 6(2), 68-80.

[3] WHO. (2012). Water Safety Planning for Small Community Water Supplies-step-by-step Risk Management Guidance for Drinking-water Supplies in Small Communities. In: Report of the World Health Organization. Geneva. 
[4] UNDP. (2006). Human Development Report, Beyond Scarcity: Power, Poverty and the Global Water Crisis, New York.

[5] WHO/UNICEF. (2006) Joint Monitoring Programme for Water Supply and Sanitation Coverage Estimates for Drinking Water.

[6] Gadgil A. (1998). Drinking Water in Developing Countries. Annual Review of Energy and the Environment, 23(1), 253-286.

[7] Momba MNB and Notshe TL. (2003). The microbiological quality of groundwater-derived drinking water after long storage in household containers in a rural community of South Africa. Journal of Water Supply: Research and Technology-Aqua, 52(1), 67-77.

[8] Van der Merwe V, Duvenage S and Korsten L. (2013). Comparison of biofilm formation and water quality when water from different sources was stored in large commercial water storage tanks. Journal of Water and Health, $11(1), 30-40$.

[9] Arampatzi SI, Giannoglou G and Diza E. (2011). Biofilm formation: A complicated microbiological process. Aristotle University Medical Journal, 38(2), 21-29.

[10] Hall-Stoodley L, Costerton JW and Stoodley P. (2004). Bacterial biofilms: from the natural environment to infectious diseases. Nature Review Microbiology, 2(2), 95-108.

[11] Ma L, Conover M, Lu H, Parsek MR, Bayles K and Wozniak DJ. (2009). Assembly and development of the Pseudomonas aeruginosa biofilm matrix. PLoS Pathogens, 5(3), e1000354-e1000354.

[12] Oliveira NM, Martinez-Garcia E, Xavier J, Durham WM, Kolter R, Kim W and Foster KR. (2015). Biofilm Formation As a Response to Ecological Competition. PLoS Biology, 13(7), e1002191.

[13] Tolker-Nielsen T and Molin S. (2000). Spatial Organization of Microbial Biofilm Communities. Microbial Ecology, 40(2), 75-84.

[14] Donlan RM. (2002). Biofilms: microbial life on surfaces. Emerging Infectious Diseases, 8(9), 881-890.

[15] Costerton JW. (1999). Introduction to biofilm. International Journal of Antimicrobial Agents, 11(3-4), 217-221, discussion 237-219.

[16] Sanchez CJ, Mende K, Beckius ML, Akers KS, Romano DR, Wenke JC and Murray CK. (2013). Biofilm formation by clinical isolates and the implications in chronic infections. BMC Infectious Diseases, 13(47), 1-12.

[17] Dötsch A, Eckweiler D, Schniederjans M, Zimmermann A, Jensen V, Scharfe M, Geffers R and Häussler S. (2012). The Pseudomonas aeruginosa transcriptome in planktonic cultures and static biofilms using RNA sequencing. PloS One, 7(2), e31092-e31092.

[18] Sauer K, Camper AK, Ehrlich GD, Costerton JW and Davies DG. (2002). Pseudomonas aeruginosa displays multiple phenotypes during development as a biofilm. Journal of Bacteriology, 184(4), 1140-1154.

[19] Anderson GG and O'Toole GA. (2008). Innate and Induced Resistance Mechanisms of Bacterial Biofilms. In: Bacterial Biofilms. Edited by Romeo T, vol. 322. Berlin, Heidelberg: Springer Berlin Heidelberg, 85-105.

[20] Mah T-FC and O'Toole GA. (2001). Mechanisms of biofilm resistance to antimicrobial agents. Trends in Microbiology, 9(1), 34-39.

[21] Fux CA, Costerton JW, Stewart PS and Stoodley P. (2005). Survival strategies of infectious biofilms. Trends in Microbiology, 13(1), 34-40.

[22] Characklis WG, Nevimons MJ and Picologlou BF. (1981). Influence of Fouling Biofilms on Heat Transfer. Heat Transfer Engineering, 3(1), 23-37.

[23] James GA, Beaudette L and Costerton JW. (1995). Interspecies bacterial interactions in biofilms. Journal of Industrial Microbiology, 15(4), 257-262.

[24] Jagals P, Jagals C and Bokako TC. (2003). The effect of container-biofilm on the microbiological quality of water used from plastic household containers. Journal of Water and Health, 1(3), 101-108.

[25] Momba MN and Kaleni P. (2002). Regrowth and survival of indicator microorganisms on the surfaces of household containers used for the storage of drinking water in rural communities of South Africa. Water Research, 36(12), 3023-3028. 
[26] Parsek MR and Singh PK. (2003). Bacterial biofilms: an emerging link to disease pathogenesis. Annual Review of Microbiology, 57, 677-701.

[27] Packiyam R, Kananan S, Pachaiyappan S and Narayanan U. (2016). Effect of Storage Containers on Coliforms in Household Drinking Water. International Journal of Current Microbiology and Applied Sciences, 5(1), $461-477$.

[28] Okore V (2009). Principles of Pharmaceutical Microbiology, 2nd edn. Enugu, Nigeria: Ephrata Publishers.

[29] Razvi N, Awan R, Naqvi S, Anjum DF, Hussain Z and Farooqi S. (2014). Estimation of Microbial Contamination in Various Active Pharmaceutical Ingredients and Excipients, vol. 3.

[30] Adeola A, Opara MI and Adeleye IA. (2012). Microbial quality of some non-sterile pharmaceutical products sourced from some retail pharmacies in Lagos. African Journal of Microbiology Research, 6, 4903-4907.

[31] Cheesbrough M. (2006). District Laboratory Practice in Tropical Countries, 2 edn. Cambridge: Cambridge University Press.

[32] Cheesbrough M. (2002). Biochemical tests to identify bacteria. Laboratory Practice in Tropical Countries, Cheesbrough M (eds) Cambridge edn, 63-70.

[33] Sandle T. (2016). Microbiological culture media. In: Pharmaceutical Microbiology. Oxford: Woodhead Publishing, 47-61.

[34] Alemu A, Moges F, Shiferaw Y, Tafess K, Kassu A, Anagaw B and Agegn A. (2012). Bacterial profile and drug susceptibility pattern of urinary tract infection in pregnant women at University of Gondar Teaching Hospital, Northwest Ethiopia. BMC Research Notes, 5(1), 197.

[35] Jamal M, Tasneem U, Hussain T and Andleeb S. (2015). Bacterial Biofilm: Its Composition, Formation and Role in Human Infections. Research \& Reviews: Journal of Microbiology and Biotechnology, 4(3).

[36] Baird R. (2007). Microbial Spoilage, Infection Risk and Contamination Control. In: Hugo and Russell's Pharmaceutical Microbiology. Blackwell Science Ltd, 263-284.

[37] An YH and Friedman RJ. (1998). Concise review of mechanisms of bacterial adhesion to biomaterial surfaces. Journal of Biomedical Materials Research, 43(3), 338-348.

[38] Lehtola MJ, Torvinen E, Kusnetsov J, Pitkänen T, Maunula L, von Bonsdorff C-H, Martikainen PJ, Wilks SA, Keevil CW and Miettinen IT (2007). Survival of Mycobacterium avium, Legionella pneumophila, Escherichia coli, and caliciviruses in drinking water-associated biofilms grown under high-shear turbulent flow. Applied and Environmental Microbiology, 73(9), 2854-2859.

[39] Watson CL, Owen RJ, Said B, Lai S, Lee JV, Surman-Lee S and Nichols G. (2004). Detection of Helicobacter pylori by PCR but not culture in water and biofilm samples from drinking water distribution systems in England. Journal of Applied Microbiology, 97(4), 690-698.

[40] Mackay WG, Gribbon LT, Barer MR and Reid DC. (1998). Biofilms in drinking water systems: a possible reservoir for Helicobacter pylori. Journal of Applied Microbiology, 85(S1), 52S-59S.

[41] Rogers J and Keevil CW. (1992). Immunogold and fluorescein immunolabelling of Legionella pneumophila within an aquatic biofilm visualized by using episcopic differential interference contrast microscopy. Applied and Environmental Microbiology, 58(7), 2326-2330.

[42] Rajagopal R, Nair GK, Mini M, Joseph L, Saseendranath MR and John K (2013). Biofilm formation of Pasteurella multocida on bentonite clay. Iranian Journal of Microbiology, 5(2), 120-125.

[43] Rogers J, Dowsett AB, Dennis PJ, Lee JV and Keevil CW. (1994). Influence of Plumbing Materials on Biofilm Formation and Growth of Legionella pneumophila in Potable Water Systems. Applied and Environmental Microbiology, 60(6), 1842-1851.

[44] Tang RJ and Cooney JJ. (1998). Effects of marine paints on microbial biofilm development on three materials. Journal of Industrial Microbiology and Biotechnology, 20(5), 275-280.

[45] Verran J and Whitehead K. (2005). Factors affecting microbial adhesion to stainless steel and other materials used in medical devices. The International Journal of Artificial Organs, 28(11), 1138-1145.

[46] Zeng G, Vad BS, Dueholm MS, Christiansen G, Nilsson M, Tolker-Nielsen T, Nielsen PH, Meyer RL and Otzen DE. (2015). Functional bacterial amyloid increases Pseudomonas biofilm hydrophobicity and stiffness. Frontiers in Microbiology, 6(1099). 
[47] Rummel CD, Jahnke A, Gorokhova E, Kühnel D and Schmitt-Jansen M. (2017). Impacts of Biofilm Formation on the Fate and Potential Effects of Microplastic in the Aquatic Environment. Environmental Science \& Technology Letters, 4(7), 258-267.

\section{How to cite this article}

Ezenobi NO, Ogbu HI and Eneogwe NC. (2018). Microbiological assessment of biofilm formation on different water storage containers. GSC Biological and Pharmaceutical Sciences, 5(3), 115-123. 